\title{
Optimizing rumen and milk quality with top-dress hay
}

\begin{abstract}
This perspective article provides grounds to urge the modern ruminant husbandry to create capacities to benefit from top-dress forage provision. Modernization in nutrition and management has given rise to a variety of metabolic disorders in dairy and beef farming. Overfeeding starch has decreased forage effectiveness in maintaining healthy rumen and intermediary metabolism. As such, efficacious feasible on-farm strategies are needed to help secure both rumen and host against health issues and production losses. Top-dress delivery of adequately long forage choices is a practical and appetizing approach to improving nutrient intake and rumen conditions in highproducing ruminants.
\end{abstract}

Keywords: top dress, forage, ruminant husbandry, management
Volume 6 Issue I - 2017

\author{
Akbar Nikkhah \\ Department of Animal Sciences, Faculty of Agricultural Sciences, \\ University of Zanjan, Iran
}

Correspondence: Akbar Nikkah, Department of Animal Sciences, Faculty of Agricultural Sciences, University of Zanjan, National Elite Foundation, Iran, Email anikkha@yahoo.com

Received: October 12, 2017 | Published: January 30, 2017

\section{Analytical discussion}

The rapid growth of ruminant husbandry in many regions has caused many health problems that largely contribute to devastating economy losses. High levels of milk and beef production have been realized by feeding overly high levels of starch and fat. On the other hand, fertility and longevity have dramatically declined. Preparing total mixed rations to dilute the energy content of super diets usually fed to high-merit ruminants has been introduced as a strategy to reduce risks from rumen over-fermentation and consequent health and immune problems. ${ }^{1-4}$ However, such a presumed efficacy has been under serious questions. ${ }^{5-8}$ The real initial problem is not how to prepare or deliver diets to high-producing ruminants, but it is rather how to formulate diets that maintain reasonable rumen and host health while wisely and not overly improving production properties. ${ }^{9-12}$

Because of feeding too much concentrate and starch, mixing forage and concentrate may significantly reduce forage fibre effectiveness within a suboptimal subacidotic rumen environment. ${ }^{1-3}$ Overfeeding starch and fat and then mixing them with forages hoping to eradicate problems is just self-cheating. That could be a reason why component feeding proves more effective than total mixed ration delivery under certain management systems. ${ }^{1,2}$ Top-dress delivery of adequately effective forage choices helps ensure that metabolically pressured ruminants receive reasonable amount of physically effective fibre at least once daily. This separate forage provision acts as an appetizer while providing the rumen with sufficient effective fibres to stimulate ruminating, chewing, and timely naturalized rumen conditions. As a consequence, overall daily intake can be improved, which is of utmost importance in early postpartum dairy cows suffering from negative nutrient balances.

Wet and ensiled forages are better suited for total mixed rations preparation, as they embrace small concentrate particles and improve meal and bout uniformity. For top-dress presentation, however, dry forages would be more appropriate. Top-dress alfalfa and mixed legume-grass hays would be among optimal choices. Notable, the amount of top-dress forage offered must not be too much of a good thing to not increase nutrient imbalance and not reduce nutrient and feed efficiency.

\section{Conclusion}

This perspective article discussed the necessity and efficacy of top-dress forage provision in modern dairy and beef farming for the healthy management of ruminant husbandry and human food production. Top-dress and delicate provision of adequately long and physically effective forages is a workable strategy to improve food intake and rumen conditions. This on-farm approach works towards sustainable ruminant husbandry and food safety and security. But, too much of a good thing hurts.

\section{Acknowledgements}

Thanks to the Ministry of Science Research and Technology, National Elite Foundation, and University of Zanjan for supporting the author's global initiatives and programs of optimizing science edification in the new millennium.

\section{Conflict of interest}

The author declares no conflict of interest.

\section{References}

1. Nikkhah A. A pragmatic analysis of TMR vs. Component nutrition for dairy cows: a real wisdom. World J Vet Sci. 2005;3:1-2.

2. Nikkhah A. Revisiting feeding systems in postmodern ruminant agriculture: challenging the TMR. EC Agriculture. 2014;1(1):21-22.

3. Nikkhah A. The forage art in managing component feeding:a persistent on-farm success. EC Agriculture. 2015;1(1):104-105.

4. NRC (National Research Council). Nutrient Requirements of Dairy Cattle. 7th ed. Natl Acad Sci Washington DC, USA: NRC; 2001.

5. Nikkhah A. Component vs. total mixed ration feeding improves peripheral energetics in high-producing lactating dairy cows. ADSA-ASAS 2015 Midwest Meeting; Des Moines, IA, USA; 2015.

6. Nikkhah A. Total mixed ration vs. component feeding does not improve individually-fed high-producing cow performance: Common wisdom challenged. Midwest Meeting; Des Moines, IA, USA; 2015.

7. Nikkhah A. Rumen microbial protein synthesis in total mixed ration vs. Component fed high-producing dairy cows. ADSA-ASAS 2015 Midwest Meeting; Des Moines, IA, USA; 2015. 
8. Nikkhah A. Relatively finer but uniformly mixed rations permit effective bunk management: a farmlot covert. Adv Dairy Res. 2015;3:2.

9. Nikkhah A. Gut adaptation to healthy starch assimilation in dairy ruminants: a lifetime development. Adv Dairy Res. 2015;3:e117.

10. Nikkhah A. Production curve management of starch nutrition in ruminants: a global biotechnique. J Bioprocess Biotechniq. 2015;5:e123.
11. Nikkhah A. Cereals bond trounces subacute rumen acidosis. Int J Vet Health Sci Res. 2015;3(1e):1-2.

12. Nikkhah A. On Energy policies in animal production: avoiding starchy explosions. Innovative energy policies. Innovative Energy Policies. 2014;3:e110. 